\title{
A 3D-QSAR model for cannabinoid receptor (CB2) ligands derived from aligned pharmacophors
}

Robert Günther*, Winnie Deuther-Conrad, Rareś Moldovan, Steffen Fischer, Peter Brust

From 8th German Conference on Chemoinformatics: 26 CIC-Workshop

Goslar, Germany. 11-13 November 2012

Cannabinoid (CB) receptors have gained much attention as markers for various brain tumours and potential therapeutic targets of neuropathic pain and mood disorders. Two CB receptors have been cloned and described: CB1, predominantly expressed in the brain and $\mathrm{CB} 2$, primarily found in the peripheral system but also in brain. The CB2 receptor is suggested to be involved in various neurodegenerative diseases, such as Alzheimer's or Parkinson's disease [1]. Early and non-invasive diagnosis and therapy monitoring of such diseases is desired. Positron-Emission-
Tomography (PET) allows imaging of functional processes in living humans. For this, compounds with positron emitting labels like $18 \mathrm{~F}$ are used. Due to the high sensitivity of PET, such radiotracers must bind to the target protein with high selectivity.

Here, we utilise AutoGPA [2] implemented in the modelling suite MOE (Chemical Computing Group Inc., Montreal) to compute grid potentials build upon a 3D-QSAR model derived from a library of CB2 selective N-Aryl-oxadiazolyl-propionamides. Since a proper alignment of the

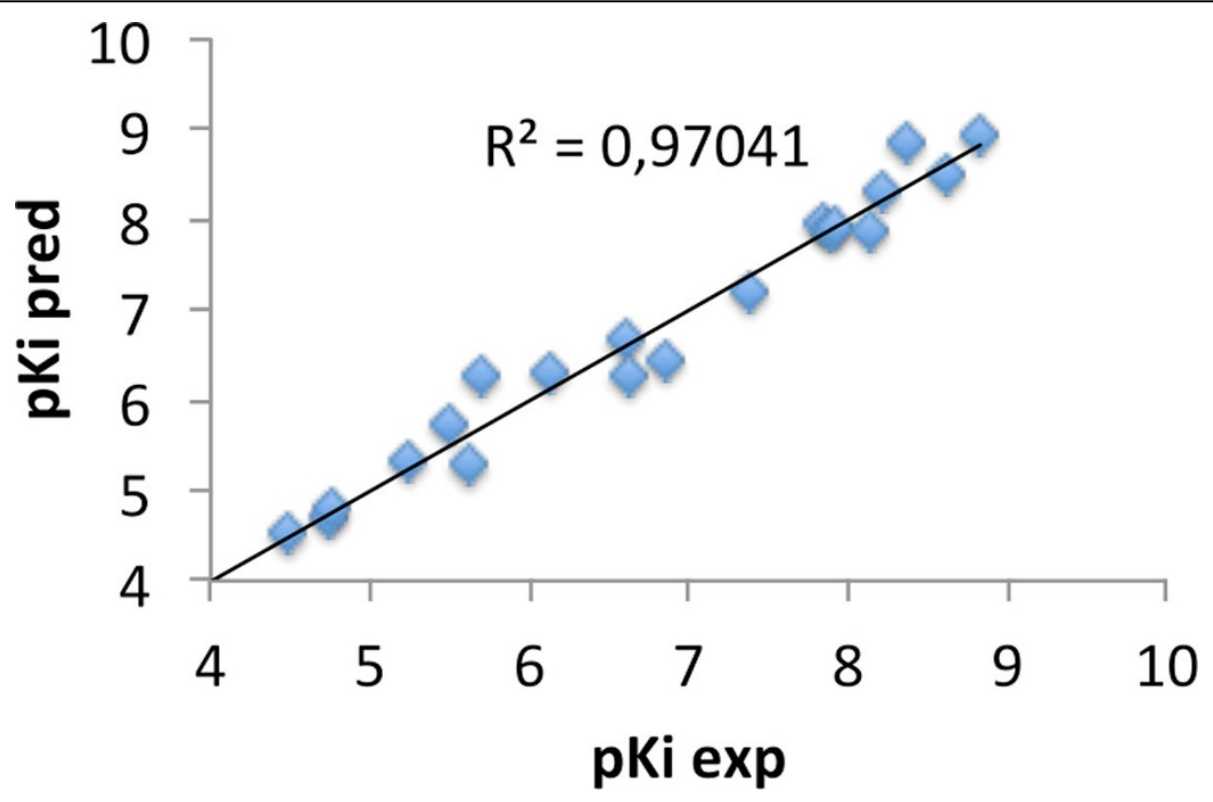

Figure 1

* Correspondence: r.guenther@hzdr.de

Dept. Neuroradiopharmaceuticals, Institute of Radiopharmacy, Helmholtz-

Zentrum Dresden-Rossendorf, Leipzig-Site, Leipzig, 04368, Germany 
molecules prior the analysis is crucial to the successful application of these models in further studies, the molecules were aligned based on their pharmacophore features. The obtained model delivers also knowledge of the 3D-structure of the binding site, which, in turn, can be used to refine 3D-models of the CB2 receptor. The steric and electrostatic contour maps are applied for identification of regions suitable for labelling with $18 \mathrm{~F}$, the most preferred PET radionuclide.

Published: 22 March 2013

\section{References}

1. Scotter EL, Abood ME, Glass M: The Endocannabinoid System as a Target for the Treatment of Neurodegenerative Disease. Br J Pharmacol 2010, 160:480-498.

2. Asakawa N, Kobayashi S, Goto J, Hirayama N: AutoGPA: A novel 3D-QSAR method based on grid potential analysis and pharmacophore alignment Poster presentation at 10th InCoB - 1st ISCB Asia Joint Conference (InCoB2011/ISCB-Asia 2011); Kuala Lumpur, Malaysia.

doi:10.1186/1758-2946-5-S1-P40

Cite this article as: Günther et al:: A 3D-QSAR model for cannabinoid receptor (CB2) ligands derived from aligned pharmacophors. Journal of Cheminformatics 2013 5(Suppl 1):P40.

\footnotetext{
Publish with ChemistryCentral and every scientist can read your work free of charge

"Open access provides opportunities to our colleagues in other parts of the globe, by allowing anyone to view the content free of charge." W. Jeffery Hurst, The Hershey Company.

- available free of charge to the entire scientific community

- peer reviewed and published immediately upon acceptance

- cited in PubMed and archived on PubMed Central

- yours - you keep the copyright

Submit your manuscript here:

http://www.chemistrycentral.com/manuscript/<smiles>c1ccccc1</smiles> 